\title{
The Beginning of the End of the Climate Drama
}

\author{
Jan-Erik Lane ${ }^{1}$ \\ ${ }^{1}$ Professor emeritus at UNIGE, Geneva, Switzerland \\ Correspondence: Jan-Erik Lane, Professor emeritus at UNIGE, Geneva, Switzerland.
}

Received: July 3, 2018

Accepted: July 19, 2018

Available online: July 24, 2018

doi:10.11114/ijsss.v6i8.3476

URL: https://doi.org/10.11114/ijsss.v6i8.3476

\begin{abstract}
Climate and Earth scientists have launched the new theory of abrupt climate change, which entails a most real threat to human survival. They clarify Hawking irreversibility by multiple so-called tipping points. The COP21 project seems bound for coordination failure. And country resilience will not suffice against the consequences of abruot climate change, involving inter alia much sea level rise and constantly increasing heat for decades as well as hurricanes and forest fires.
\end{abstract}

Keywords: energy, tipping points, irreversible Hawking development, COP21 Treaty, PD gaming, reneging

\section{Introduction}

The prospects for decarbonisation halting climate change seems grim, especially if abrupt climate change theory is correct. The crux of the matter is energy, which still comes with a high corbon intensity in most countries. Energy is the capacity to do work, which is the foundation of affluence. Figure 1 brings this fact out clearly for 2017.

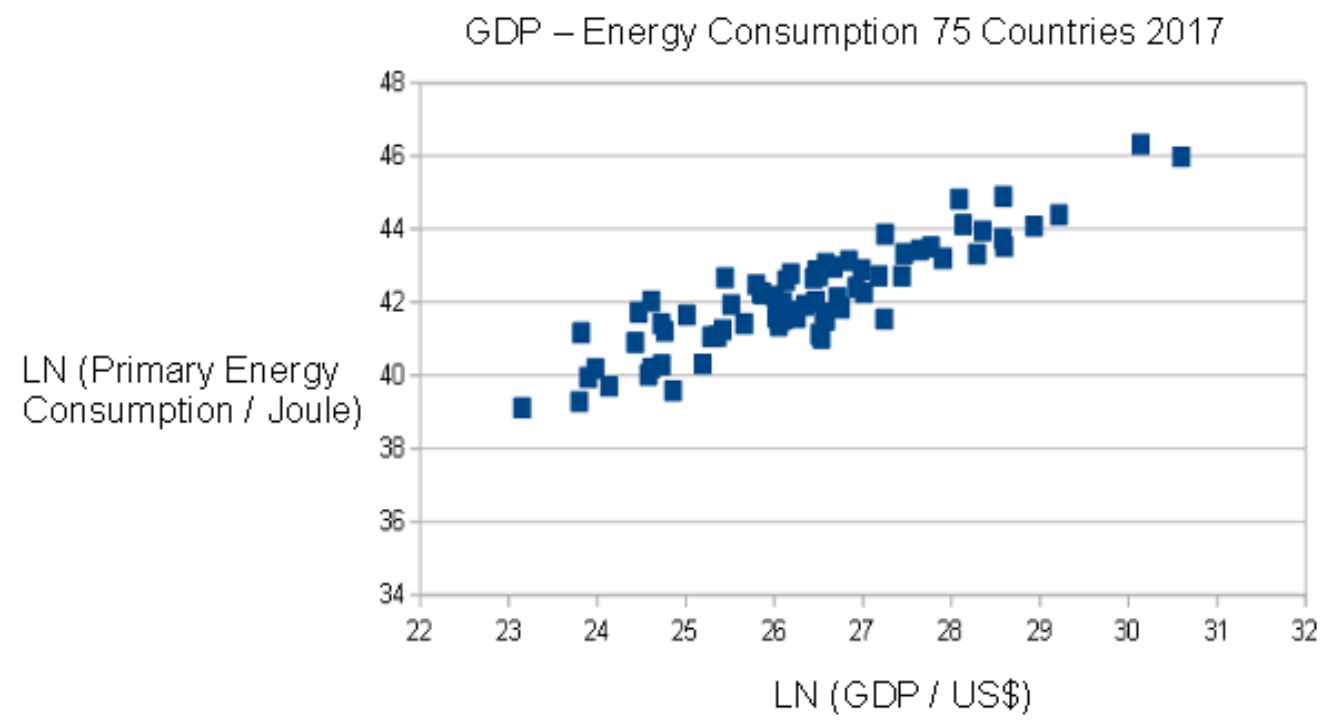

Figure 1. GDP and energy for the globe 2017

Sources: Bp Statistical Review of World Energy

World Bank Data Indicators

Note. $\mathrm{R} 2=0.81$

\section{Coordination Failure}

The COP21 Treaty, or any other similar agreement, would have two parts:

i) reduction of $\mathrm{CO} 2$ emissions ina certain pace towards zero emissions at some future date;

ii) contributions to the Super Fund yearly according to some scheme and time table. 
Both these two actions concern first and foremost the countries in the G20 group of nations, responsible for 70 per cent of the total $\mathrm{CO} 2$ emissions. Small poor nations can be left beside, as they pollute little and cannot be required to pay into the Super Fund.

Both i) and ii) are just promises, which the COP21 Secretariat or the UN cannot enforce, strictly speaking. When a country receives support the Super Fund, there is some leverage to force obedience. However, a big poor country may simply refuse decarbonisation, if no assistance is provided.

Decarbonisation is costly in the short run for all countries, as the must replace existing energy plants with new, hopefully renewable energy resources. Contriuting to the Super Fund is also costly in the short run. This sets up an interaction where a government may be tempted to defect from its promises to decarbonise or pay to the Super Fund.

A. Stratey of poor nations: the $\mathbf{N}-1$ problematic. Poor or small nations will engage in opportunism with guile in order to avoid too large costs with the COP21 decarbonisation policy, pretending they matter very little for outcomes.

B. Strategy of the rich country: the 1/N problematic. Large or rich countries will find sacrifices that cannot be internalised as meaningless gifts to others, who may not be trusted to cooperate. Thus, the US reneged because it did not want to pay for decarbonisation in India.

The PD nature of interaction in a global CPR like the COP21 Treary is fragile, to say the least. What is lacking is the instruments of control, as Hobbes pointed out already 1651 in hid Leviathan, speaking of voluntary agreements or accords:

\section{"Covenants, without the sword, are but words, and of no strength to secure a man at all,"}

\section{Ineffective Resilience}

Governments only pay lip service to the threat of human extinction. It is business as usual among the Great Powers, in the Middle East and South China Sea, in markets and financial institutions. This is not what climate and earth scientists would predict, but it is in accordance with social science theories of collective action. No time for utopian experiments, as time is tight (Stern, 2007, 2015).

The chart below shows carbon intensity (fossil fuels/all energy) for a selection countries in the world. This is root cause of abrupt climate change, threatening mankind. The mean is as high as $85 \%$.

Chart of Carbon Intensity

\begin{tabular}{|c|c|}
\hline - $\quad$ Norway & - $31,1 \%$ \\
\hline - $\quad$ Sweden & - $\quad 33,4 \%$ \\
\hline - $\quad$ Switzerland & - $\quad 52,1 \%$ \\
\hline - $\quad$ France & - $\quad 53,5 \%$ \\
\hline - Finland & - $\quad 55,8 \%$ \\
\hline - $\quad$ Brazil & - $\quad 62,9 \%$ \\
\hline - $\quad$ New Zealand & - $\quad 63,1 \%$ \\
\hline - Canada & - $\quad 65,0 \%$ \\
\hline - $\quad$ Austria & - $\quad 67,5 \%$ \\
\hline - Colombia & - $\quad 68,6 \%$ \\
\hline - $\quad$ Ecuador & - $\quad 71,6 \%$ \\
\hline - $\quad$ Peru & - $\quad 72,8 \%$ \\
\hline - Ukraine & - $\quad 73,5 \%$ \\
\hline - $\quad$ Spain & - $\quad 76,2 \%$ \\
\hline - $\quad$ Romania & - $\quad 76,3 \%$ \\
\hline - $\quad$ Vietnam & - $\quad 78,8 \%$ \\
\hline - $\quad$ Chile & - $\quad 78,9 \%$ \\
\hline - $\quad$ Belgium & - $\quad 79,0 \%$ \\
\hline - $\quad$ Czech Republic & - $\quad 79,4 \%$ \\
\hline - United Kingdom & - $\quad 80,0 \%$ \\
\hline - $\quad$ Germany & - $\quad 80,2 \%$ \\
\hline - $\quad$ Portugal & - $\quad 80,9 \%$ \\
\hline - $\quad$ Hungary & - $\quad 80,9 \%$ \\
\hline - $\quad$ United States & - $\quad 84,2 \%$ \\
\hline - Italy & - $\quad 84,8 \%$ \\
\hline - China & - $\quad 86,4 \%$ \\
\hline - $\quad$ Sri Lanka & - $\quad 86,5 \%$ \\
\hline - $\quad$ Argentina & - $\quad 86,6 \%$ \\
\hline - $\quad$ South Korea & - $\quad 87,2 \%$ \\
\hline • $\quad$ Turkey & - $\quad 87,4 \%$ \\
\hline - Russian Federation & - $\quad 87,4 \%$ \\
\hline - $\quad$ Philippines & - $\quad 87,9 \%$ \\
\hline
\end{tabular}




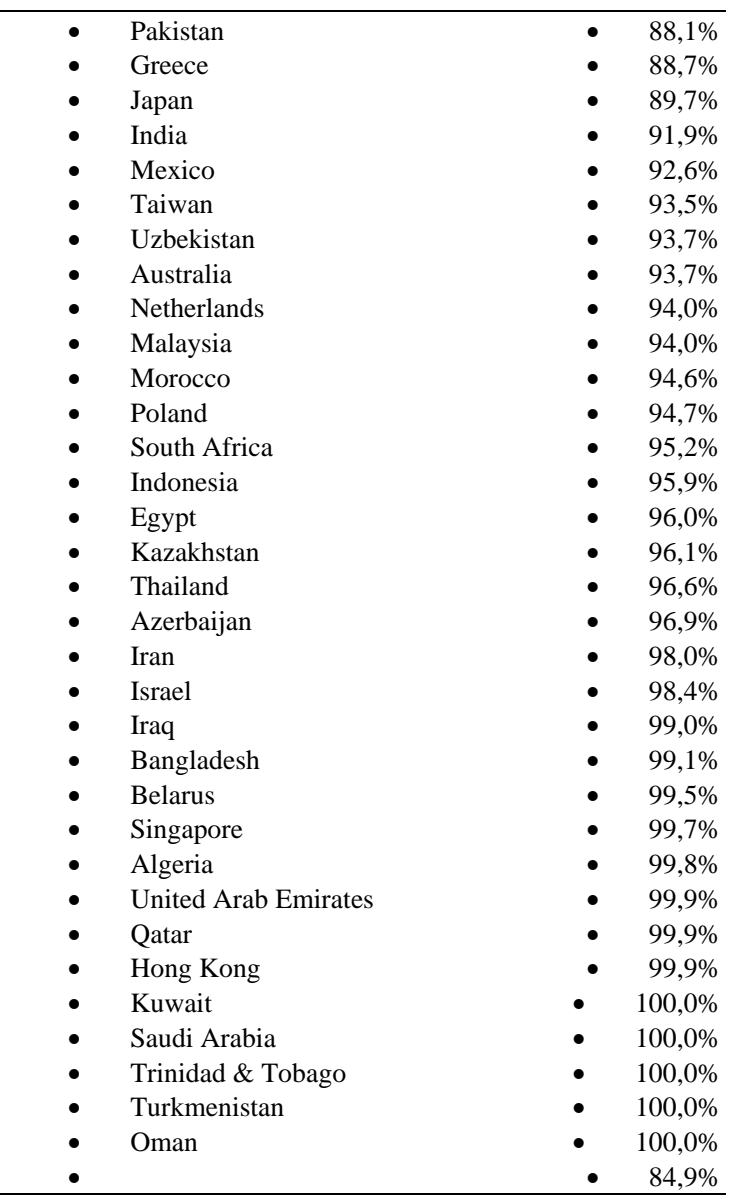

Sources: BP Statistical Review of World Energy

The crux of resilience as strategy is energy, which still comes with a high corbon intensity in most countries. Energy is the capacity to do work, which is the foundation of affluence and human development.

\section{The Anthroposcene Period: Likely End of Mankind?}

Scholars now say we face a new period in the history of human beings on Earth, the anthroposcene replacing the holoscene period. It would be characterised by mankind's domination over Nature, resulting in a quite new climate and ecological degradation. Yet, one could retork that it is now Nature that shrinks the degrees of freedom of men and women, making them victims of Nature's unpredictability and violence.

In this perspective, the holoscene period antedating the anthroposcene beginging arund 1700, lasted for thousands of years. How long will the anthoposcene period last? The COP21 Accords were based on a belief that time was available for a slow decarbonisation, managing global warming at around +2 degrees Celsius, stabilising climate sometimw 2076 - the carbon budget approach. These beliefs are now partially outdated.

\section{Abrupt Climate Change Theory}

Recently launched, climate and earth scientists now focus upon so-called tippng points as well as the great variability in temperature increases over the entire globe. The dramatic changes in the Arctic have made researchers focus upon the melting of the ice at the poles and Greenland and its repurcussions for global weather and the huge methane holdings in the permafrost from Alaska to Siberia, both on land and in ocean.

a) Tipping point 1: Arctic Sea ice; Expected to disappear around 2020, it will not increase sea levels dramatically due to the eqivalence between ice and water. But this will affect global oceans streams as well as global weather yet streams.

b) Tipping point 2: Greenland ice; Uncertainty when it will be gone - some say 1940, this will raise sea levels some 6 meters. Major city areas will inundated: Miami, Rio de Janeiro, Venice, Kairo-Alexandria, Mumbai, Hanoi, Shanghai, Tokyo and Singapore, for instance. It would further deteriorate oceans conveyor belt and the slow the global yet stream.

c) Tipping point 3: Antartica ice mass; this enormous mass of ice and glaciers would be finished by some 100-500 years, rising sea levels some 60-70 meters. Mankind stand to loose a lot of land all over the planet Earth - a true catastrophe. 
d) Tipping point 4: constant heat increase with draught and potable water scarcity. This would reuce food availability and lead to millions of climate refugees from vunerable low level coastline countries and poor nations along the equator.

e) Tipping point 5: Methane emissions from the melting permafrost. This threat is so huge that mankind would never survive such a major release of $\mathrm{CO} 2 \mathrm{~s}$.

The idea of so-called tipping points is that it make concrete the Hawking notion of irreversibility.

\section{Irreversibility: Its Entailment}

When S. Hawking suggested that climate change was irreversible, he was met wih sharp citicism. The notion of an irreversible process of change comes from the theory of scientific laws of nature with their universality and empirical necessity. If global warmin is unstoppable or inevitable, then the survival of the human race is at stake.

The only way to reduce the speed of climate change, avoiding inevitability, is to stop pumping GHGs into the atmosphere. This requires inter alia:

i) immediate stop to coal and charcoal in poor countries;

ii) replacing fossil fuel enegy with solar panel parks of the Morroccan Quarzazate kind;

iii) initiate now large scale geo-engineering experiments to suck up $\mathrm{CO} 2 \mathrm{~s}$ or sequestrate $\mathrm{CO} 2 \mathrm{~s}$..

Will these measures be taken by the UNFCCC or the G20 group of nations? Probably not. Why? Becaause of the ocean PD game involved. What matters to all countries and governments is access to energy, the culprint of the anthroposcene period.

\section{Energy and Human Needs}

The public and private sectors demand lots of energy to produce their goods and services. Energy, or the capacity to do work potentially or actually, is key in economic growth for enterprises and financula institutions in rich countries. And energy is absolutely essential in socio-econmic development in poor nations. But energy supply drives the emisions of GHGs, as energy consumption results in GHG emissions as long as fossil fuels dominate supply. Figure 2 shows most recent data abou the iron link between GDP, or economic output, and energy consumption, globally.

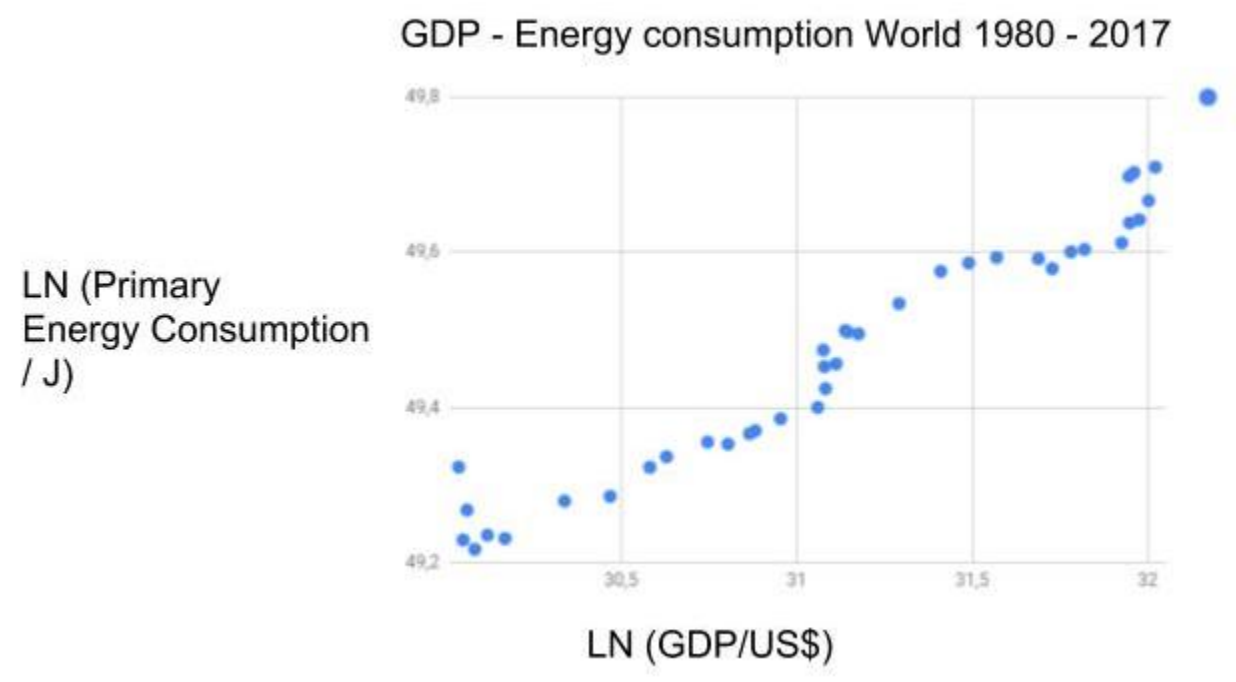

Figure 2. GDP and Energy

Note. $\mathrm{R} 2=0.951$

Sources: Bp Statistical Review of World Energy

World Bank Data Indicators

The cental position of economic growth in rich countries and of socio-economic development in poor countries is much in consonance with basic human drives as well as with the logic of vibrant capitalism in the global market economy. Governments and politicians cherish economic growth, because it makes more policy-making possible. Look at the evidence about the positive effects of energy in the figures below, linking energy consumption with human development indicators, 
The living conditions in the poor countries in Latin America, Africa and Asia as well as the Pacific reflects the low level of energy employed. This basic fact determines life opportunities in a most dramatic fashion. The low access to energy has consequences for the environment and the life situation of people, including health, schooling, work, food and potable water.

For instance, African countries are poor because they have too little energy. Thus, they have much less GHGs than Asia. Yet, they need the COP project of the UNFCCC to renew their energy sources and move from fossil fuels and traditional renewables to solar power. Hydro power depends upon water availability that shrinks with global warming.

African energy deficit is conducive to a dire environment with enormous damages and risks. Consider the following global figures. Figure 4 shows how low energy leads to am unsafe environmental.

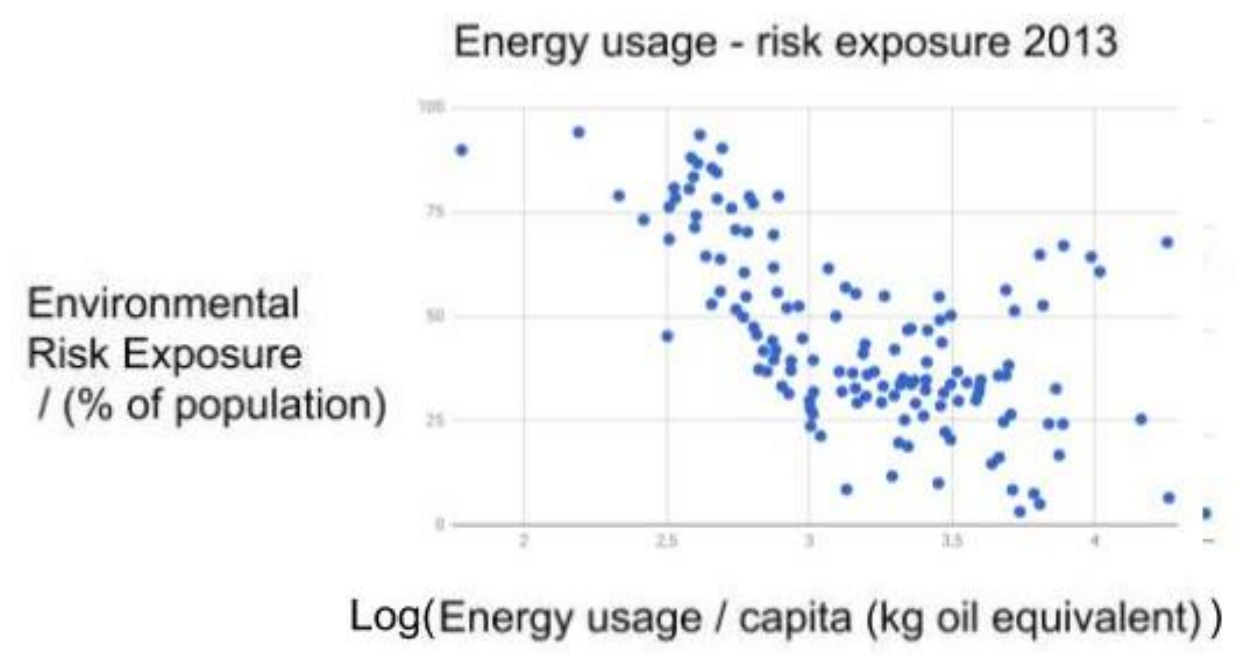

Figure 3. Energy and environmental risk exposure

Source: Environmental Performance Index, Yale University, https://epi.envirocenter.yale.

IEA Statistics @ OECD/IEA 2014 (http://www.iea.org/stats/inde

Low energy use leads to poverty, malnutrition, deceases, lack of potable water, insufficient sanitation, etc. Typical of many Latin American, African and Asian nations is the lack of stable electricity, which hampers everything and reduces environmental viability. Figure 5 has the global picture.

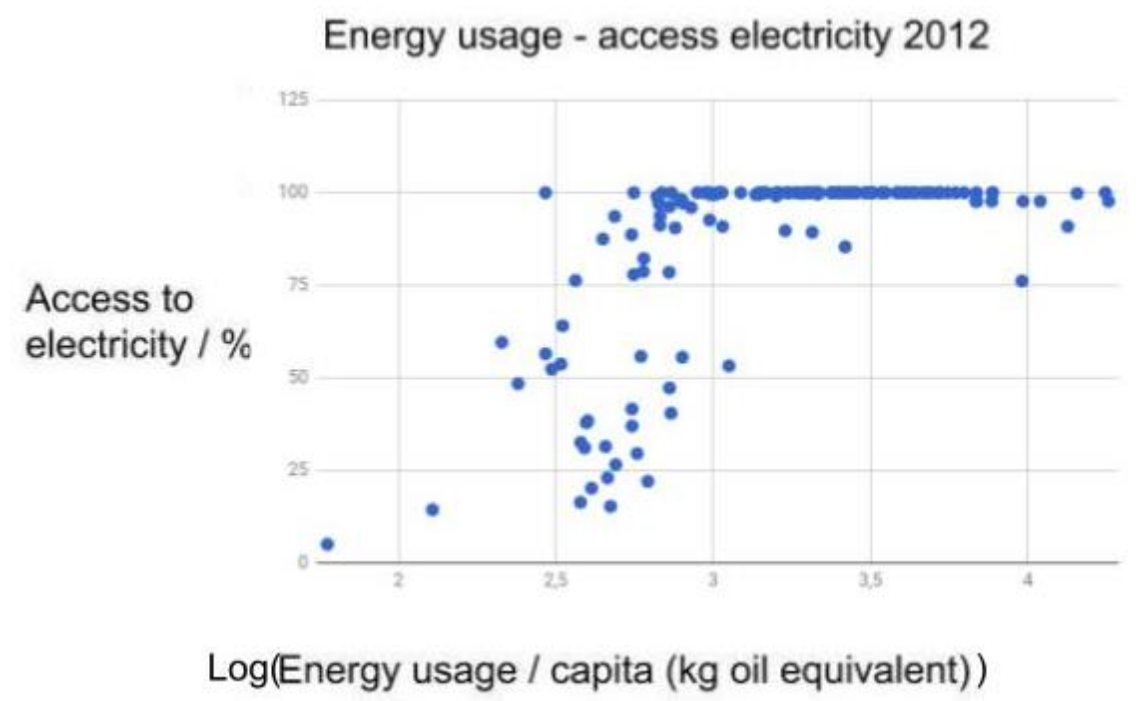

Figure 4. Energy and Electricity Access

Source: Environmental Performance Index, Yale University, https://epi.envirocenter.yale.

IEA Statistics @ OECD/IEA 2014 (http://www.iea.org/stats/inde 
The access to safe and stable electricity is crucial for health, schools, food, water, etc. Figure 6 links energy with proper sanitation.

\section{Energy usage - access sanitation 2014}

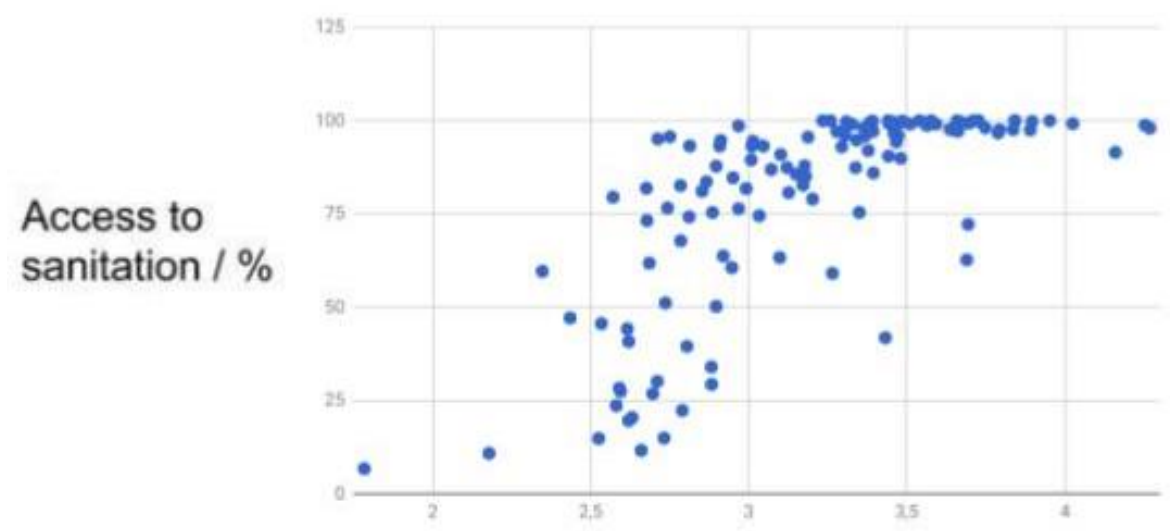

\section{Log(Energy usage / capita (kg oil equivalent))}

Figure 5. Sanitation and Energy

Source: Environmental Performance Index, Yale University, https://epi.envirocenter.yale.

IEA Statistics @ OECD/IEA 2014 (http://www.iea.org/stats/index)

Especially, the rapidly growing African, Latn American and Asian mega-cities lack entirely proper sewage plants. Thus, dirty water is put into the big rivers where other cities downstream take their potable water.

The access to safe and stable electricity is crucial for health, schools, food, water, etc. Figure 4 links energy with proper sanitation.

\section{Energy usage - access sanitation 2014}

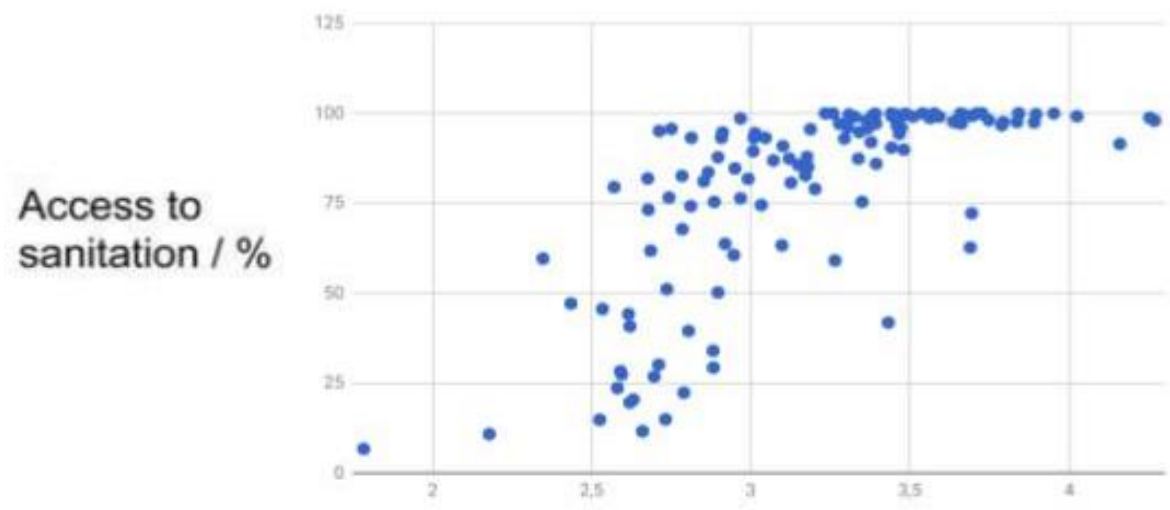

\section{Log(Energy usage / capita ( $\mathrm{kg}$ oil equivalent))}

Figure 6. Sanitation and Energy

Source: Environmental Performance Index, Yale University, https://epi.envirocenter.yale.

IEA Statistics @ OECD/IEA 2014 (http://www.iea.org/stats/inde

Figure 7 underscores the necessity of more energy in poor coutries for prper sanitation, without which the life of humans is "salle". 


\section{Energy usage - unsafe sanitation 2014}

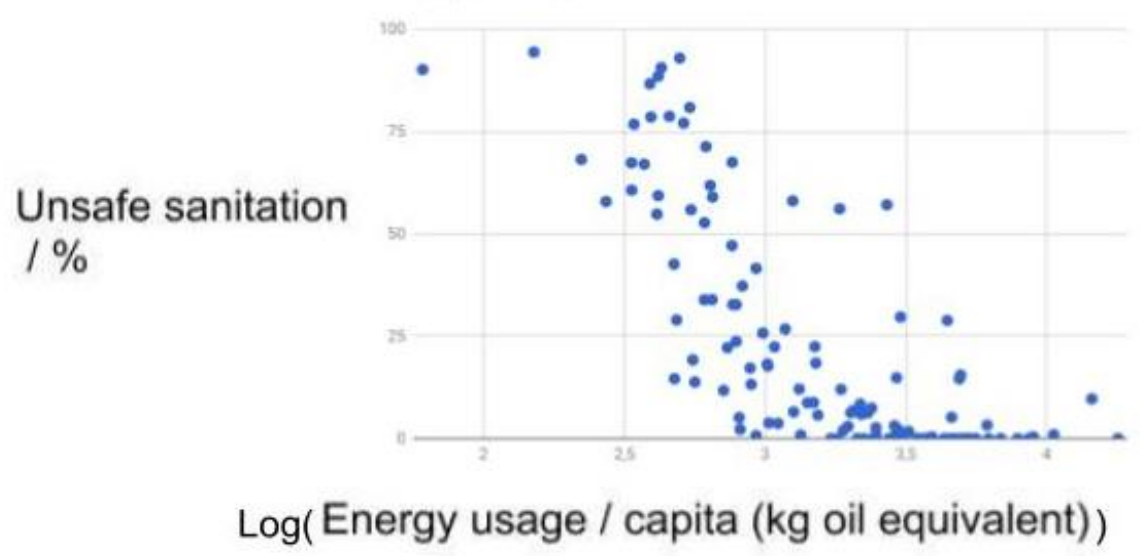

Figure 7. Energy and Unsafe Sanitation

Source: Environmental Performance Index, Yale University, https://epi.envirocenter.yale. IEA Statistics @ OECD/IEA 2014 (http://www.iea.org/stats/inde

Air quality too depends upon energy access (Figure 8).

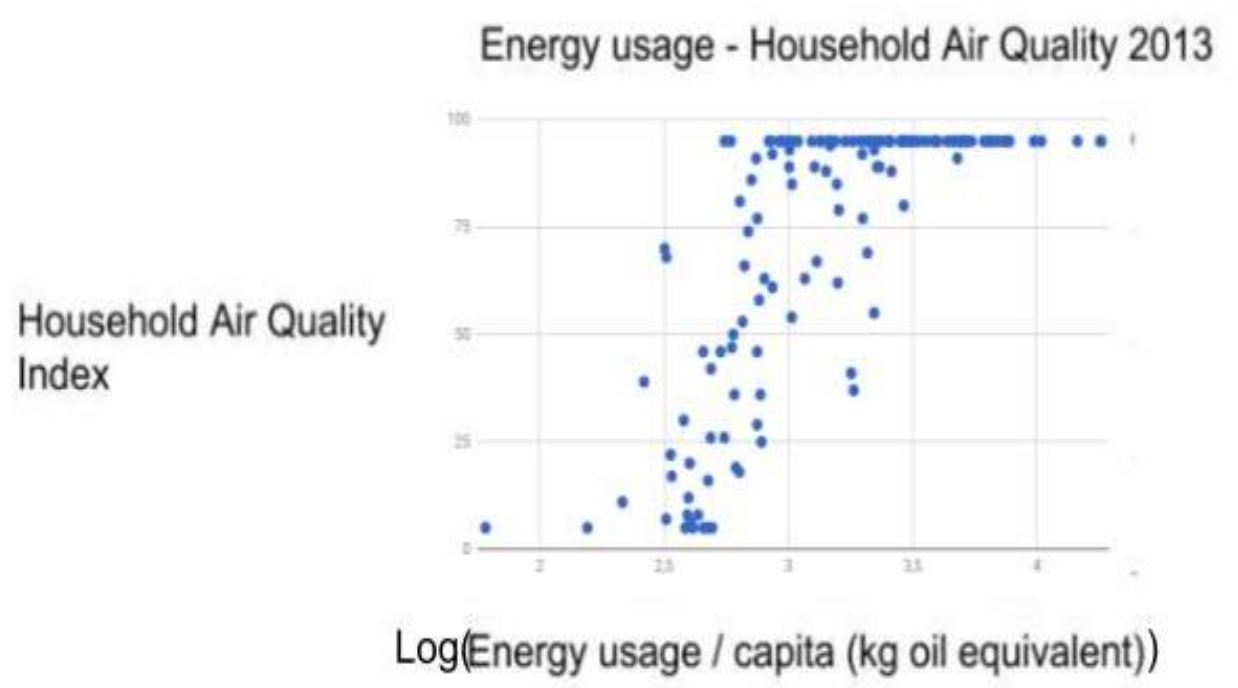

Figure 8. Energy and Air Quality

Source: Environmental Performance Index, Yale University, https://epi.envirocenter.yale.

IEA Statistics @ OECD/IEA 2014 (http://www.iea.org/stats/inde

Typical of many poor nations - Latin America, Africa, Asia - is the lack of predictable access to safe electricity, which hampers work and reduces environmental viability. The access to safe electricity is, it must be emphasized, absolutely central for health, schools, food, potaable water, etc. Given the lack of enough energy in poor countries being conducive to the above bad living conditions, one understands the hopes of the poor countries for help with energy transformation leading to better access to just energy!

Given the above evidence about the positive consequences of energy for quality of life and life opportunities, one understand the position of the Third World at the Paris meeting that decarbonisation must be combined with great econoic assistance to make fundamental energy transfrmation. The result was the promise if a giant Super Fund, bit it is only a promise. 


\section{Projection of Energy: A Few Examples}

The decrbonisation goal of COP21 requires the support of the big countries in the world. But do they really aim at decarbonisation? We look at three examples here.

India

In Indian energy policies, it is emphasized that developmental goals take precedence over climate change considerations. Thus, all Indian household musst have access to electricity and only sustained rapid economic growth can reduce poverty. India has a "take-off" economy that delivers affluence for the first time since independence. But it is based on fossil fuels. India looks into other sources of energy, as long as socio-economic development is not hindered. Figure 9 shows the main features of India's future planning.

\section{Projected Primary Energy Supply From Different Sources In 2022 \& 2040}

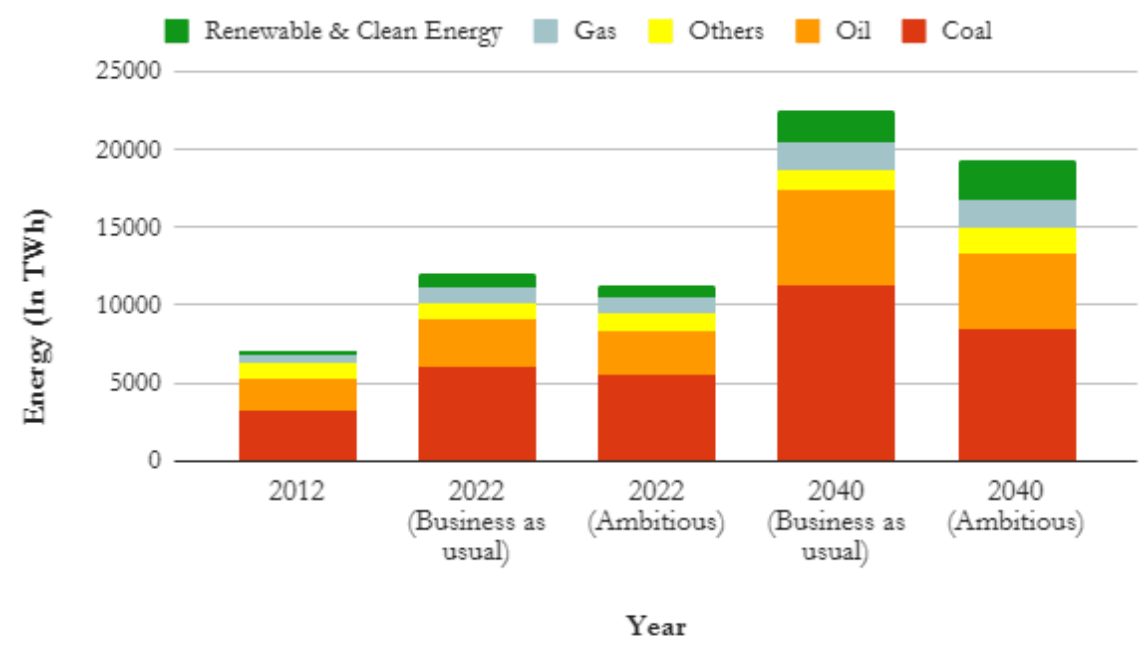

Figure 9. India`s energy future

Source:

https://scroll.in/article/843981/indias-new-energy-policy-draft-projects-coal-fired-capacity-will-double-by-2040-is-thatfeasible

India has rapidly become a major CO2 emitter due to its high growth rates since 1990. It uses lots of coal, stone or wood. Charcoal is bad for households and results in forest destruction. India tries to broaaden its energy supply to modern renewables, like solar, wind and hydro power. Yet, it will remain stuck with fossil fuels for decades. It needs assistance from the COP21 project, especially for solar power parks. Building more dams is very risky, as global warming reduces water assets. Figure 9 indicates the India cannot meet its COP21 promises, as Ramesh (2015) underlines.

India shows the same close link betwee GDP and energy consumption (Figure 10). 


\section{GDP - Energy consumption India 1980 - 2017}

\section{LN (Primary Energy Consumption / J)}

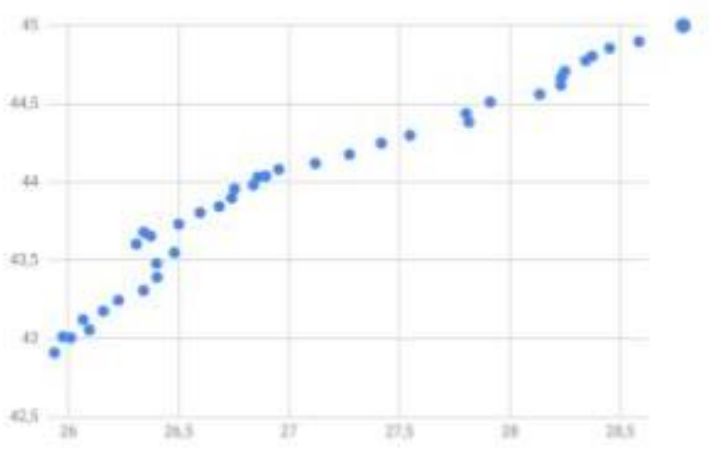

\section{LN (GDP/US\$)}

Figure 10. GDP and energy in India

Note. $\mathrm{R} 2=0.94$

Sources: Bp Statistical Review of World Energy

World Bank Data Indicators

Given this close connection between GDP and energy consumption in India, the risk is of course that further socio-economic developments will increase GHG emissions. India is hardly on the decarbomisation road.

USA

The US has reduced its $\mathrm{CO} 2$ emissions during the lats years, mainly by a shift to natural gas. Actually, several mature economies have been able to halt the rise of $\mathrm{CO} 2$ emissions, either by more energy efficiency or a shift to natural gas or renewables. Figure 11 captures some features in US energy plans.
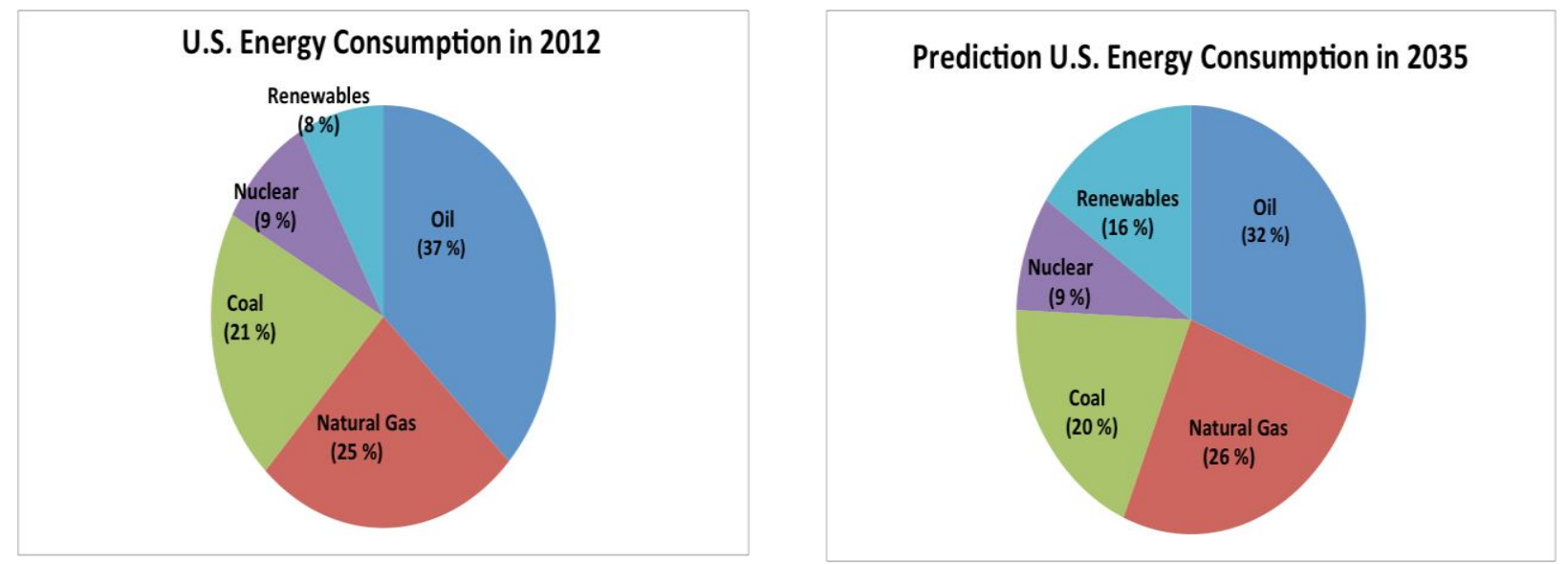

Figure 11. US energy future

Source: https://www.e-education.psu.edu/egee102/node/1930

Although the Figure 9 predicts a doubling of renewable energy, the dependency upon fossil fuels, including coal energy, will not bee much reduced. We are talking here about relative numbers, but if the US increases total amount of energy supply - fracking!, then there may even be more fossil fuels. The reduction in $\mathrm{CO} 2 \mathrm{~s}$ during recent years seems to be coming at a reduced rate. The hope is for economic growth without energy increases, but we are not there yet. And most countries demand more energy for the future. 


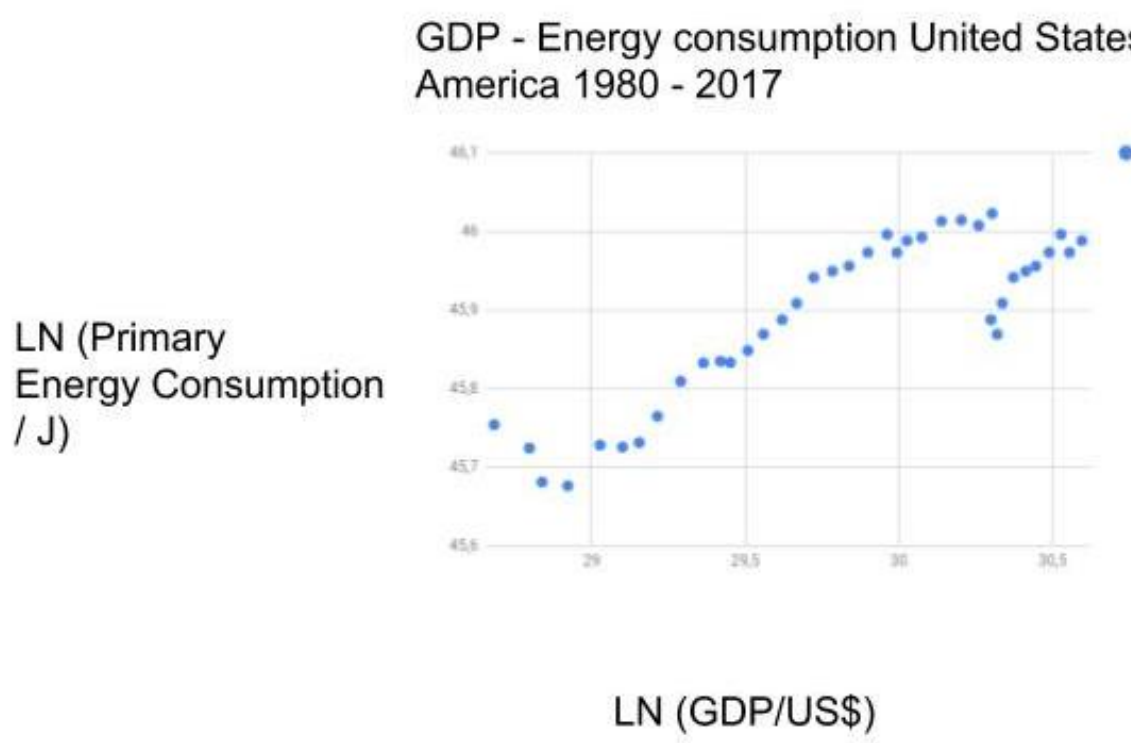

Figure 12. GDP and energy for the USA

Note. $\mathrm{R} 2=0.77$

Sources: Bp Statistical Review of World Energy

World Bank Data Indicators

Although the link between GDG and energy consumption id lress tight for he USA than India, reflecting that economic growth in advanced countries can be achieved without energy increase, it is still the case that the US is not on the road towards major decarbonisation.

\section{China}

China now enters the First World, as it has long passed its "take-off" point in time around 1980 and has pursued a successful "catch-up" policy for a few decades. Its energy consumption, especially fossil fuels, has skyrocketed with GDP, resulting in the largest $\mathrm{CO} 2$ emission globally. Figure 13 has a projection for China.

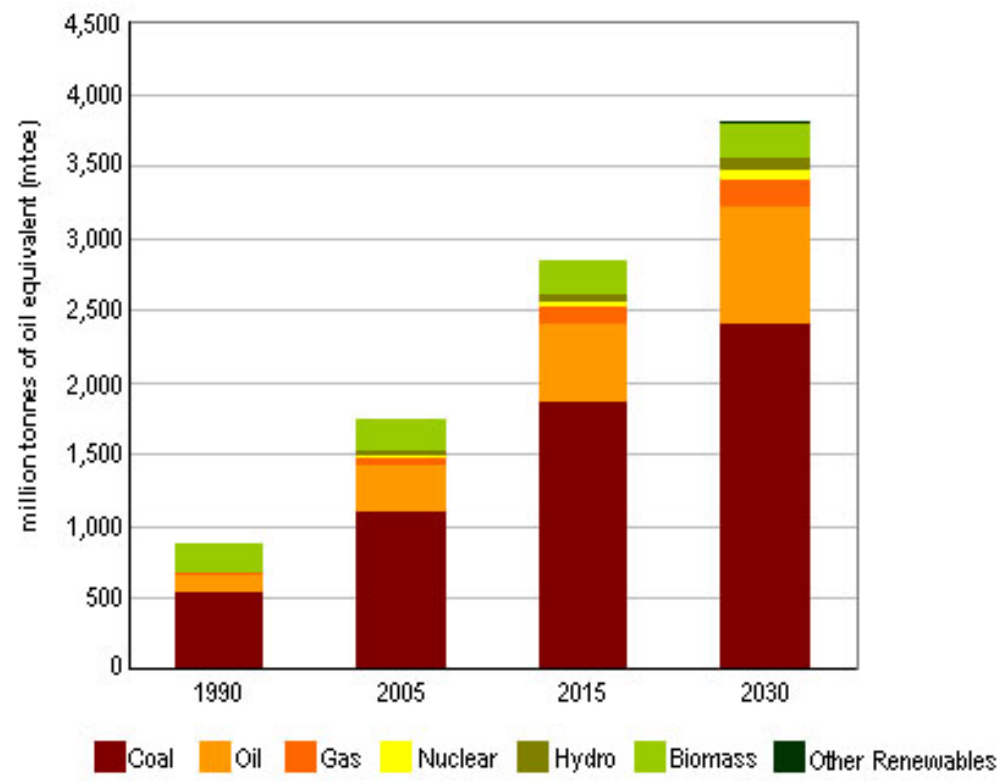

Figure 13. Energy Projection For China

http://www.wrsc.org/attach_image/chinas-projected-energy-growth-fuel 
Decarbonisation does not seem highly probable. Much hope was placed at a recent reduction in $\mathrm{CO} 2 \mathrm{~s}$, but water shortages forced China to revert to coal in 2017 with attending augmentation of CO2s. China is investing in both renewables and atomic power, but it also plans for large energy increase in the coming decades with lots of energy consuming new projects.

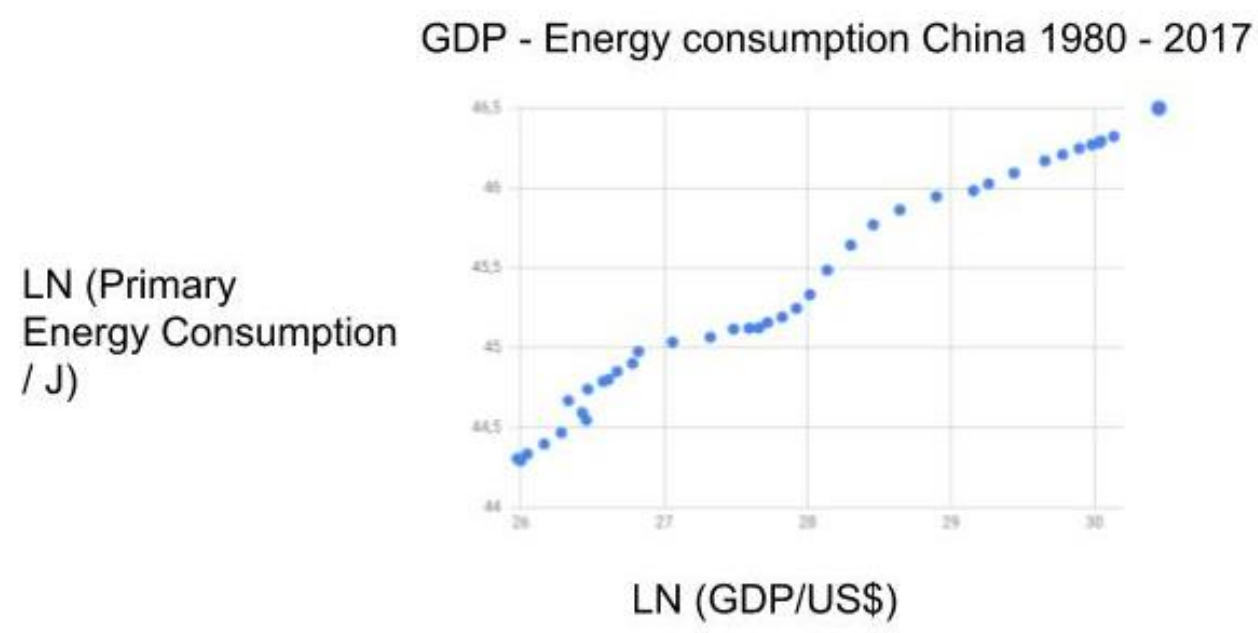

Note. R2 $=0.98$

Figure 14. GDP and energy for China

Sources: Bp Statistical Review of World Energy

World Bank Data Indicators

Such a close connection between GDP and energy consumtion in China imples that China must turn to renewables massively in order to comply with COP21 goals.

\section{Domestic Policy Concerns and International Coordination}

A government may bind the state it repesents to farreaching objectives like complete decarbonisation at an internatinal reunion, but it is just a "scrap of paper". It matters really press cncerning safeguarding national interests, the goverment simply reneges. When water becomes scare for Chinese energy dams. Then coal is resorted to again, with new $\mathrm{CO} 2$ augmentation.

Domestic politics play a major role in energy policy besides international accords. Here are three examples

a) Japan's dilemma

After the Fukushima disaster, Japan closed 50 of its 52 reactors. The country relies much upon the import of of various energy resources. Will Japanese politics allow a return ro nuclear power or will Japan like South Korea rely massively upon LNG from Australia? One possible scenario is ourlined in Figure 15- 


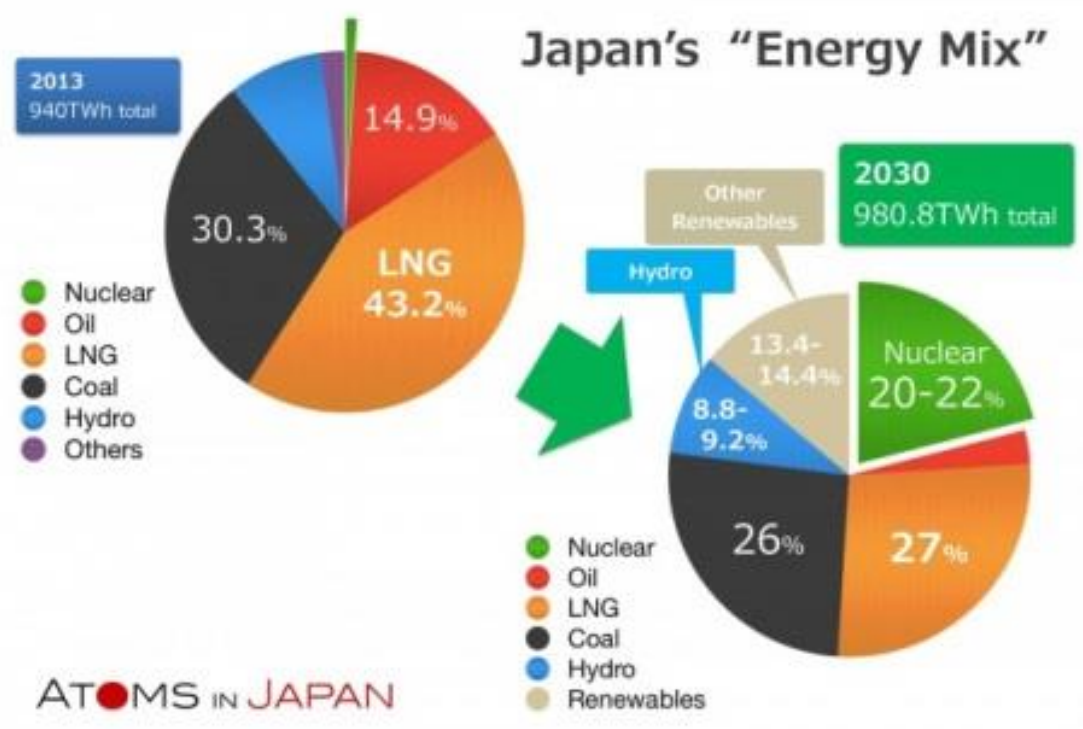

Figure 15. Energy plans for Japan

Source: http://www.world-nuclear-news.org/NP-Plan-sets-out-Japans-energy-mix-for-2030-0306154.html

b) Germany \& France: nucleaar distrust

Despite all propaganda about so-called Energiwende, Germany remain much dependent upon fossil fuels. High grade coal is imported from Russia and Colombia to add to its own low grade coal, besides all the natural gas from Gazprom. At the same time, nuclear power are closing - all up to 2022. France is also closing nuclear plants, despite the fact that they could be used longer and made safer. Both countries should turn to solar power - see Table 1, but may be expected to burn biomass or biotrash, which emits $\mathrm{CO} 2$ inter alia.

Table 1. Number of Ouarzazate plants for 40 per cent reduction of $\mathrm{CO} 2$ in some giant countries (Note: Average of 250 300 days of sunshine used for all entries except Australia, Indonesia, and Mexico, where 300 - 350 was used).

\begin{tabular}{llll}
\hline Nation & \multicolumn{1}{c}{$\begin{array}{c}\text { Co2 reduction pledge / } \\
\text { \% of 2005 emissions }\end{array}$} & $\begin{array}{c}\text { Number of gigantic solar } \\
\text { plants needed (Ouarzazate) }\end{array}$ & $\begin{array}{c}\text { Gigantic plants needed for } \\
\text { 40 \% reduction }\end{array}$ \\
\hline United States & $26-28^{\mathrm{i}}$ & 2100 & 3200 \\
China & none $^{\mathrm{ii}}$ & 0 & 3300 \\
EU28 & $41-42$ & 2300 & 2300 \\
India & none & 0 & 600 \\
Japan & 26 & 460 & 700 \\
Brazil & 43 & 180 & 170 \\
Indonesia & 29 & 120 & 170 \\
Australia & $26-28$ & 130 & 190 \\
Russia & none & 0 & 940 \\
Germany & $49^{\mathrm{ii}}$ & 550 & 450 \\
France & $37^{\mathrm{v}}$ & 210 & 220 \\
Sweden & $42^{\mathrm{v}}$ & 30 & 30 \\
World & N/A & N/A & 16000 \\
\hline
\end{tabular}

Note. i) The United States has pulled out of the deal; ii) No absolute target; iii) Pledge is above current level, no reduction; iv) Upper limit dependent on receiving financial support; v) EU joint pledge of $40 \%$ compared to 1990.

c) Swedish folly 
Sweden used to be lucky with energy resources, relying upon many rivers and modern high tech and very safe nuclear power stations. However, since 2000 it now abandons nuclear power at astronomical costs, relying instead upon the import of biomass or biotrash. GHG are now increasing in Sweden.

Summing up: Climate change is more lethal than nuclear power plant accidents.

\section{Conclusion}

The awareness of lethal climate change is on the increase with scientists, civil society and ordinary people. But the political elites remain myopic and opportunistic. The 21 st century may be the last in the history of human beings. Why is there no action from G20 nations?

\section{References}

Solar power sources

Paris 2015: Tracking country climate pledges. Carbon Brief, https://www.carbonbrief.org/paris-2015-tracking-country-climate-pledges

EDGAR v 4.3.2, European Commission, Joint Research Centre (JRC)/PBL Netherlands Environmental Assessment Agency. Emission Database for Global Atmospheric Research (EDGAR), release version 4.3.2. http://edgar.jrc.ec.europe.eu, 2016 forthcoming

CO2 Emission Reduction With Solar

http://www.solarmango.com/in/tools/solar-carbon-emission-reduction

i The United States has pulled out of the deal
ii No absolute target
iii Pledge is above current level, no reduction
iv EU joint pledge of $40 \%$ compared to 1990

\section{Copyrights}

Copyright for this article is retained by the author(s), with first publication rights granted to the journal.

This is an open-access article distributed under the terms and conditions of the Creative Commons Attribution license which permits unrestricted use, distribution, and reproduction in any medium, provided the original work is properly cited. 